Pobrane z czasopisma Annales I - Philosophy and Sociology http://philosophia.annales.umcs.pl Data: 26/04/2023 14:49:04

10.1515/sectio-2015-0021

A N N A L E S

UNIVERSITATIS MARIAE C URIE-SKŁODOWSKA

L U B L I N - P O L O N I A

VOL. XL, 1

SECTIO I

2015

Universidad Complutense de Madrid

ÁNGELES JIMÉNEZ PERONA

\title{
Critical Thought and Feminism in the Spanish Enlightenment ${ }^{1}$
}

Pensamiento crítico y Feminismo en la Ilustración español

\section{THE “WOMEN'S QUESTION” AND THE UNIFIED CONCEPT OF THE SPECIES IN EUROPEAN ENLIGHTENMENTS}

The critical feminist thought in the Spanish Enlightenment shares certain features with all modern European Enlightenments. This is hardly surprising, since they all - despite their different backgrounds - stem from a common source: the feminist thought that evolved in modern times in $17^{\text {th }}$ - and $18^{\text {th }}$-century France. This French feminist thought is itself entrenched in the entire political philosophy surrounding the construction of the modern State and the corresponding new social order.

In fact, what takes place in Europe (first in France, and later everywhere else) is not so much "feminist" thought (an anachronistic expression), but a radically new chapter in the old "Women's Question" (La querelle des femmes). However although the term feminism dates from the $19^{\text {th }}$ century, I use it in this essay as a convenient shorthand to refer to this concept.

There were several factors that contributed significant new developments to this age-old dispute, one of which was social; namely that the "dispute about women" was no longer in the hands of theologians. Since the Renaissance, new social spaces had gradually been opened up where the women's question was debated both collectively and publicly. These were above all social spaces in which women themselves had a voice. In the $17^{\text {th }}$ century, these were the salons

1 Text written as part of research project entitled "Normativity and praxis: the debate after Wittgenstein" (FFI2010-15975), Ministry of Economy and Competitiveness, and the Complutense research group on "Critical materialism" (9330664). 
Pobrane z czasopisma Annales I - Philosophy and Sociology http://philosophia.annales.umcs.pl Data: 26/04/2023 14:49:04

of high-society ladies (noblewomen and the bourgeoisie), where regular meetings were arranged and attended by some of the leading lights in society and culture to discuss issues of cultural and social interest. In the following century, political debates gradually took on greater importance. In $17^{\text {th }}$-century France these events were known as "salons précieux", the organisers of which Molière set out to ridicule in this play Les Précieuses ridicules (The pretentious young ladies).

In addition to this, it should be recalled that Europe at that time was undergoing a period of profound crisis at all levels. This crisis would lead to the abandonment of the mediaeval world for the modern; and the substitution of the old social and political order with a new one in which the idea of equality took predominance over all systems of privilege. The same crisis in philosophy spurred the development of a new concept of human beings that would be compatible with the new social and political order that was taking shape. In France, this crisis would eventually culminate in the French Revolution.

The other novel factor in the dispute over women was of an intellectual nature. Defenders of women relied on the new philosophy that began to emerge as a result of this anthropocentric shift. More specifically, they based their arguments on the new unified concepts of the species preached by the philosophy of the day, and which crystallized in the models of the subject of knowledge and the subject of action (ethical and political).

In fact, French "feminist" thinkers - both male and female - in the $17^{\text {th }}$ and $18^{\text {th }}$ century all promoted a version of the modern subject. Specifically, at the core of their reflections was the groundbreaking idea of seeing human beings from a unified standpoint; that is, as having some identifying trait that was common to them all. Generally speaking this common trait was rationality, in any of its modern philosophical versions.

This abstract view of a human being as a subject capable of having true knowledge thus led to notions of the political subject that were totally inclusive of all human beings. This political subject was described as being capable of recognising what is fair (as made explicit in the form of citizen's rights), and sovereign to morally govern over his or her own life and contribute to the organisation of a fair social and political order.

From this point on, a new image of women began to emerge as epistemic, legal, political and social subjects. In this regard we should mention, among many others, the Cartesian Poullain de la Barre, the physiocrat and liberal Marquis de Condorcet (1743-1794), and the unorthodox Rousseauian Olympe de Gouges (1748-1793).

This same trend in thinking was also to be found in Spain. Here, as in the rest of Europe, it would never become a hegemonic or majority current of thought, but it would be constant and sustained over time. In fact, the validity of some modern ideas and arguments continued to endure until the triumph of the Franco regime after the Civil War (1936-1939). 
Pobrane z czasopisma Annales I - Philosophy and Sociology http://philosophia.annales.umcs.pl Data: 26/04/2023 14:49:04

However, if we take into account the entire legacy of Spanish feminism in the $18^{\text {th }}$ century as compared with the French legacy, we can see a shift in the main focus of analysis: whereas in France the political (in general revolutionary) perspective was predominant and produced a range of social and ethical derivations, in Spain there is a greater emphasis on the social and ethical standpoint, which had reformist political consequences.

This ethical shift and the reformist political realignment were customary in other European Enlightenments, both in the feminist sector (for example, M. Wollstonecraft in the United Kingdom) and in the non-feminist sector (for example, I. Kant in Germany).

However despite this difference, there is another trait shared by both the Spanish and French Enlightenment - and in fact by all modern western Enlightenment thought - namely that they are split into two large branches according to the stand they take in the dispute over women. On the one hand we have those who defend women's social and political equality, and on the other those who oppose it. Notable opponents include J.J. Rousseau, who accompanied his political model with a social model that excluded women from the political arena of equality and fraternity ${ }^{2}$.

\section{BENITO JERÓNIMO FEIJOO: AN EMPIRICIST DEFENDER OF WOMEN}

Among the Spanish defenders of equal rights for women, the name that first comes to mind is that of the Benedictine monk Benito Jerónimo Feijoo (1676-1764).

Feijoo is not the first Spanish thinker to champion modern philosophical ideas. Here we could mention for example the novatores in the $17^{\text {th }}$ century such as Francisco Gutiérrez de los Ríos and Crisóstomo Martínez. Their thinking reveals the modern interest in scientific novelty in opposition to Thomist and Aristotelian hegemonic scholasticism. They also strove for both methodological rigour and clarity in their explanations, and even took the debate on their innovative ideas out of the university classrooms to discussion groups and academies.

Nor was Feijoo the first Spanish intellectual to construct modern arguments in favour of equality for women. Here it is worth recalling the example, among others, of Sister Juana Inés de la Cruz (1651-1695) ${ }^{3}$.

If we look at the $18^{\text {th }}$ century - the century of the Enlightenment - we cannot avoid referring to the extensive work of Feijoo entitled Teatro critico universal (Universal Critical Theatre). Of course the word 'theatre' in the title must be understood in the sense - now obsolete - of "panorama" or general overview of the

2 See particularly chapter V of his Émile, ou De l'education.

3 She was born, lived and died in the Viceroyalty of New Spain, which was at that time part of the Spanish empire, today's Mexico. 
Pobrane z czasopisma Annales I - Philosophy and Sociology http://philosophia.annales.umcs.pl Data: 26/04/2023 14:49:04

whole. Hence, this is a philosophical work containing several volumes of essays published between 1726 and 1740 to which he gave the name of discourses (in the sense of a discursive meditation).

In discourse XVI of volume I - entitled "The defence of women" - he upholds the equality of women and men in the moral, physical and intellectual spheres. It is also worth noting that Feijoo's unified concept of the species does not morally idealise human beings, as evidenced by the fact that he describes the equivalence between men and women by assigning positive and negative traits to each sex in equal measure.

Philosophically, Feijoo embraced the empiricism of Francis Bacon and his Novum Organum (1620), although he considered himself at times eclectic and at others a moderate sceptic. The authors he most often cites include - in addition to Francis Bacon - Pierre Gassendi, René Descartes, Robert Boyle, John Locke and Pierre Bayle.

In any case, his defence of women follows along empiricist methodological lines: first, he makes an exhaustive collection of examples of women considered to be capable in all areas; then he uses this data as empirical evidence for women's aptitudes, before going on to infer the unity of capabilities of humanity as a whole.

Armed with these data he sets out to refute all those who have maintained women's inferiority, starting with Aristotle himself, including Malebranche, and even venturing to interpretations of the Bible. He also looks at traditional sceptical arguments and questions the rationality of those who consider women to be intellectually inferior: "Those who wrote those books - in which women's understanding is condemned as being inferior - were men. If they had been written by women, we men would have been the inferiors"

Among his arguments, he proffers one that will become a recurrent theme in all subsequent feminist thinking, and one that reveals the logical fallacy of the view that the empirical ignorance of a large number of women is due to a lack of capabilities and not - as would be more logical - the lack of habit in exercising these capabilities: "Even the most limited logician knows that the lack of potency cannot be inferred from the lack of act; and thus the fact that women do not know more does not allow you to infer that they have no talent for knowing more"s.

It is further worth noting his thesis that souls have no gender. In this he coincides fully with the Cartesian Poullain de la Barre, and this idea is the ultimate ground for the metaphysical unification of the species, given that having soul - or spirit - is regarded by the philosophy of the day as humanity's distinguishing feature.

4 B.J. Feijoo, Discurso XVI. Defensa de las mujeres, [in:] Teatro crítico universal, Vol. 1, 1726, § IX, p. 59, www.filosofia.org/bjf/bjft000.htm (access: 10.06.2015)

5 Ibidem, § IX, p. 62. 
Pobrane z czasopisma Annales I - Philosophy and Sociology http://philosophia.annales.umcs.pl Data: 26/04/2023 14:49:04

But Feijoo's theory is not a rationalist feminist one, nor does he have a rationalist concept of the subject ${ }^{6}$. Unlike the Cartesian Poullain de la Barre, Feijoo accompanies his metaphysical and theological reflections with others on physics, as he subscribes to the ontological continuity between soul, understanding (or discursive capacity) and body. This idea of ontological continuity leads to strong theoretical conflicts in Feijoo's thinking, which are very significant for the history of feminist theory, as they appear in other later theories which set out to oppose them, each in their own way. However the most interesting aspect lies in the fact that these theoretical conflicts expose some key issues in the thinking on the identity of human beings.

One of these can be seen in the text where Feijoo attempts to reconcile the ideas he has reached through philosophical reasoning, with those of the divine mandate he encountered in his study of the Bible. For example, the whole of section $\S \mathrm{VI}$ is devoted to providing empirical evidence of women who are examples of political prudence. Feijoo thus refutes all those who considered women to be incapable of possessing political virtues, and at the same time justifies the idea that women could exercise a legitimate authority that implied being obeyed by men.

In the last point of this same section of his work ${ }^{7}$ Feijoo moves from empirical and immanent analysis (in the natural order) to a theological and transcendental analysis (in the supernatural order), where he finds the divine decree for the general obedience of women. Here he calls for a flexible interpretation of the divine mandate, in order to avoid giving rise to such ridiculous situations as preferring to proclaim a male foetus king in preference to the woman bearing the child.

This issue arises once again in section $\S$ XXIII near the end of the text, where it is resolved by assuming that the political subjection of women decreed by God is the result of original sin, and did not exist in the earlier state of innocence. A further argument is that God's purpose in assigning men priority in the government of the household and family merely obeyed reasons of utility; in other words, as a means of avoiding confusion and disorder. In this peculiar way, Feijoo posits the equality of talents and skills between men and women, while justifying the domestic obedience of women.

This conflict ceases to be seen in subsequent feminist theories from the point when the divine text is no longer considered relevant to the organisation of human life on this earth. For example, the French Enlightenment thinkers who defended the women's cause - such as the Marquis of Condorcet and Olimpe de Gouges - believed that the equality of capacities implies that no individual or group is destined to obey, not even in the case of women in the domestic sphere ${ }^{8}$.

6 In spite of the dominant stereotype of classical feminist theories, they were not all rationalist, nor did they overlook the body when considering what unified human beings.

7 Ibidem, $\S 40$.

8 Condorcet argues that there is no reason at all to prevent the sharing of decision-making, nor, in cases where there is a need for a dominant voice, that this should always be a man's. Cf. on 
Elsewhere, other sectors of the feminist tradition for whom the Bible continued to be important - such as the suffragist feminism in $19^{\text {th }}$-century United States - resolved this conflict by means of a wholesale egalitarian reinterpretation of the Bible. It is worth noting on this point that Elizabeth Cady Stanton (1815-1902) promoted the version known as The Woman's Bible, which stands as one of the most important historical and intellectual events in feminist theology.

Another conflict that runs through the work of Feijoo and is illustrative in terms of the history of feminist thought is between his abstract anthropological analysis and his reflections on the body. The first leads him to conclude the equality of capacities, while the second can be seen as an effort to present as unsustainable any justification of social and political inequality based on bodily differences.

As is widely known, this is a recurring problem in the empirical and corporal conceptions (modern and subsequent) of the subject, as the inferiorisation of women has always been (and continues to be) firmly rooted in the interpretation of the bodily differences between the individuals designated as "men" and "women". For this reason, as is also well-known, a large part of Western feminist theories are concerned with reflecting critically on the determinist essentialism governing the cultural constructions of the concept of the "normal" human body. This is undoubtedly one of the most important themes in contemporary feminist thought. However it is less widely known that some classical feminist theories of the past also contained critical reflections of this type. Feijoo's text is an excellent example of this.

Feijoo clearly opposes the conceptions of the body deriving from the medical theories of the day; in other words, from anatomy and the theory of the temperaments. He brings to bear the dialectical and argumentative weapons of scepticism and empiricism to cast doubt on the supposed truths of the theories of anatomy and the temperaments, and thus reduces them to the absurd. He presents falsifying empirical evidence (if I may be allowed to use this contemporary epistemological expression), or cites better explanations than those suggested by these theories. Finally, he points to the need to suspend judgement on these supposed medical truths. However, as his scepticism is tempered by empiricism, Feijoo also concludes that there is no difference in anatomical terms between the organs used for the discursive capacity, and that the only anatomical difference that can be sustained on evidence is between the reproductive organs ${ }^{9}$. He also maintains

this issue Lettres d'un bourgeois de New Haven à un citoyen de Virginie (1788). A similar view can be found in the final part of the text by $\mathrm{O}$. de Gouges entitled Forme du contrat social de l'homme et de la femme, which follows her Déclaration des droits de la femme et de la citoyenne (1791). This contrasts with non-feminist Enlightenment thinking which maintained the hypothesis that women are destined to obey in all spheres, either due to a natural telos or by divine decree. Rousseau and Kant are good examples of this trend. I have discussed this issue in A.J. Perona, Igualdad, [in:] C. Amorós (ed.), 10 palabras clave sobre mujer, Pamplona, Verbo Divino 1995.

9 B.J. Feijoo, op. cit., § XII, p. 80-83. 
Pobrane z czasopisma Annales I - Philosophy and Sociology http://philosophia.annales.umcs.pl Data: 26/04/2023 14:49:04

that even allowing for possible differences in strength in the dynamic of certain organs (such as the brain), this does not imply that the mental operations are any more or less perfect ${ }^{10}$.

Thus Feijoo primarily uses the resources of philosophy to advise against unquestioningly accepting scientific descriptions of human bodies as true. He also points out that the ploy of assuming the intellectual inferiority of women from their physical differences (present in the medical theories he analyses) is merely dogmatic and devoid of justification.

His theory therefore constitutes a magnificent example of the anti-determinist conception of the human being as a body, and a denunciation of the unjustified transformation of differences into inequalities.

\section{FEMINIST ENLIGHTENMENT VERSUS HEGEMONIC ENLIGHTENMENT: JOSEF AMAR Y BORBÓN VERSUS GASPAR MELCHOR DE JOVELLANOS}

Another representative of the Spanish feminist Enlightenment was Josefa Amar y Borbón (1749-1833). She was not a philosopher but a leading writer and teacher. In 1786 she published her Discurso en defensa del talento de las mujeres y de su aptitud para el gobierno y otros cargos en que se emplean los hombres (Discourse in defence of the talents of women and their aptitude for government and other positions occupied by men) ${ }^{11}$, which was followed in 1790 by her Discurso sobre la educación física y moral de las mujeres (Discourse on the physical and moral education of women $)^{12}$. In both, she argued in favour of equality between men and women in terms of "talent and application".

Her writings also condemned the social and economic - and particularly educational - circumstances that determined the situation of Spanish women. She eloquently denounced the way in which the Enlightenment thinkers excluded women from the public sphere while privately recognising their capacity to exercise political action.

Josefa Amar was outraged by the fact that women were denied a true education and then hypocritically accused of ignorance.

In opposition to this sector of the Enlightenment, she supported the thesis that both sexes were equally possessed of intellectual capabilities and the ability to use

10 Ibidem, $\S$ XV, p. 106.

11 J. Amar y Borbón, Discurso en defensa del talento de las mujeres, y de su aptitud para el gobierno, y otros cargos en que se emplean los hombres, www.ensayistas.org/antologia/XVIII/ amar-bor (access: 10.06.2015).

12 Eadem, Discurso sobre la educación física y moral de las mujeres, Madrid 1790, http:// books.google.es/books/about/Discurso sobre_la_educacion_fisica_y_mor.html?id=LGXUxYlvoOIC (access: 10.06.2015). 
them, and defended the need to educate women in the same way as men. However, it is worth pointing out that in her work these ideas are held simultaneously with an unquestioning acceptance of the social roles traditionally assigned to women.

In spite of this contradiction, her concept of education is typically Enlightenment and typically feminist (as defended by practically any classical version of western feminism): it is seen not as the mere disciplinary transfer of information, but as training in the correct use of intellectual capabilities. The objective of this model of education is that anyone should autonomously be able to recognise what is true, what is good and what is right.

Moreover, Josefa Amar also holds the Enlightenment and feminist idea of education as a socio-political instrument for the moral improvement of individuals and society. This derives from the thesis that the critical exercise of rational faculties will liberate those who exercise it from false truths and prejudices. In other words, given that J. Amar considers these prejudices and false truths to be the source of social corruption, their elimination would bring the eradication of the sources of corruption from social life and hence its regeneration.

Josefa Amar's interlocutors in this polemic - as I have just mentioned - are other Enlightenment thinkers, and not the anti-Enlightenment defenders of the old regime. The reflections on women by the Spanish hegemonic Enlightenment (as with the French) contained discourses on excellence that can certainly not be described as being consistent with political and social equality.

Indeed, the hegemonic Enlightenment has always tended to see the most important problem as being women's education, but with the aim of instilling in them the ideal of perfecting the only skills acknowledged by the Enlightenment discourse - namely the traditional skills associated with the roles of mother and wife. Instead of linking the right to education with the construction of a fair and egalitarian social and political space, the Spanish hegemonic Enlightenment redefined the stereotype of the domestic woman by adapting it to the needs of the political and cultural model of the new regime ${ }^{13}$; a manoeuvre that was very similar to Rousseau's in Émile.

Perhaps the best exponent of this hegemonic Enlightenment is Gaspar Melchor de Jovellanos (1744-1811), who in the reign of Carlos III defended the need for State-led educational reform for the purpose of accomplishing the ideals of rational criticism ${ }^{14}$.

From a theoretical point of view, it should be noted that Jovellanos severely criticised the conceptual structure of Rousseauian revolutionary republicanism.

13 A Royal Decree issued by Carlos III in 1783 establishes that boys should be taught reading, writing, counting and grammar, plus prayers and handicrafts, while girls will only be taught prayers and handicrafts. Only in the last years of the century were girls allowed to learn how to read on request. Cf. C. Sarasua, El siglo de la Ilustración, [in:] B.S. Anderson, J.P. Zinsser, Historia de las mujeres: una historia propia, Barcelona 1991, p. 613.

14 Cfr. G.M. Jovellanos, Elogio de Carlos III, [in:] Poesía, Teatro, Prosa, Madrid 1980. 
Pobrane z czasopisma Annales I - Philosophy and Sociology http://philosophia.annales.umcs.pl Data: 26/04/2023 14:49:04

In contrast, the reform of social customs proposed by Jovellanos owes something to Rousseau's moral universe, and specifically to all his moral criticism of luxury, wastefulness and the false needs of the leisured classes.

Jovellanos' theoretical framework also contains - in common with all Enlightenment thinkers including Rousseau - a unified concept of the species due to their possession of identical rational capacities. However he concurs with the whole of the antifeminist Rousseauian current of thought in using a teleological idea of nature ${ }^{15}$. Thus Jovellanos maintains that nature has ordained a different social purpose for women, and that they are not destined to develop their faculties like men, and are thus unable to perform any social role other than that of mother.

In Jovellanos' view women belonged to a class that was attached to uses, customs, rather than norms $^{16}$, and thus comprised a segment that was given to the care of everyday matters. He believed that women lacked the fear of the mechanisms of justice, and were therefore unprepared to comply with the rules and laws that govern men's actions. It is worth noting that this argument incurs in the fallacy denounced by Feijoo.

Indeed Jovellanos, true to the modern concept of criticism and progress, sought to reform Spanish society. To do so he demanded a generalised extension of education, as he considered it to be the best means of obtaining this goal. However, based on the actual condition of women at that time, he presupposed a generalised atrophy of all the essential capabilities needed to operate directly as social and political agents. In short, for Jovellanos only men were in a position to use reason to develop the sense of justice, and thus to maintain the universal civil law.

In addition to this was what he regarded as being the degeneration of the customs of the ladies of court and in large cities, where the need for class distinctions served as a pretext for waste. To counteract this Jovellanos proposed not the same yet more sober moral education for both men and women, but a differentiated education: girls should be educated to be good wives and mothers, and their schooling would be distinguished according to their social rank.

He believed that all girls should be educated in a first stage, including girls from a humble social background. Thus girls from the lower classes would be sent to free schools where they would learn reading and writing, the principles of religion and the manual skills necessary to make them into housewives. However, in the following educational stage, only girls from wealthy families would be sent to a few specific schools where they would receive a more rounded and thorough education.

15 I explored this issue in A.J. Perona, op. cit.

16 Cf. G.M. Jovellanos, Dictamen... sobre renovar o revocar la prohibición de la introducción y uso de las muselinas (1784), [in:] V. Llombart, J. Ocampo (eds.), Obras completas, Vol. 10, Oviedo 2008. 
Pobrane z czasopisma Annales I - Philosophy and Sociology http://philosophia.annales.umcs.pl Data: 26/04/2023 14:49:04

This solution is a paradigmatic example of the general strategy of non-feminist members of the European Enlightenment, who disguised the discrimination of women (along with other types of discrimination) beneath the rhetoric of the thesis of the complementarity of the social roles of each sex.

In fact the theoretical dilemma facing this current of thought was how to exclude women from the social and political sphere while simultaneously accepting a unified concept of the species, which is conveyed socially and politically in the idea of equality. Their problem was therefore how to achieve an "exclusionary inclusion" of women.

For this reason, educational reform in Spain sought to bring about a reorganisation of productive activities that would separate the private spheres of household chores from the public spheres of work. At the same time, it restricted women's participation in education, which in turn prevented them from entering the public workplace and the political arena, for which the education of their rational and abstract capabilities (only accessible to men, although not to all) was an essential condition.

The key outcome of this manoeuvre was that henceforth the domestic sphere was not only associated with certain specific activities, but - more strategically also with the transmission of values and habits which - according to the members of the Enlightenment - could not be assured by the institutions and actions of the State. Thus this repositioning of women did not reduce them merely to a life of privacy and irrationality, but endowed them with indirect access to the public arena, namely through their influence over the public space thanks to their role as mothers of social and political subjects - in other words, of men. This was a ploy to reconcile their exclusion with their equal human dignity.

Jovellanos perfectly reflected this idea in his Memoria sobre si se debian o no admitir las señoras en la sociedad económica de Madrid (Discussion on whether or not to admit ladies in the Economic Society of Madrid; 1875) and in his Memoria sobre la educación pública, o Tratado teórico-práctico de enseñanza (Discussion on public education, or Theoretical-practical treatise on education; 1802).

In the first text Jovellanos approved the admission of women in the Economic Society of Madrid. "We must do right by them", he says, "but in doing so we should not consider so much their origin, wealth or beauty, but their spirit, lively wit, decorum, humanity, goodness and charity". In other words, we need to take account of the "civil or domestic virtues by which this sex is honoured", and whose knowledge will bring a distinction to the public sphere ${ }^{17}$. Therefore, the recognition and distinc-

17 Cf. idem, Elogio de Carlos III, p. 163-162, 273-275. The most interesting problem posed by Jovellanos was: how could those virtues be linked to their actual involvement in the institution? In his view, women who attended the institution were worthy of praise, but those who did not attend the meetings should be assured that they were not excluded as they could "contribute from their homes to cooperating with us in the goals of our institute". We should add that Jovellanos did not approve of 
Pobrane z czasopisma Annales I - Philosophy and Sociology http://philosophia.annales.umcs.pl Data: 26/04/2023 14:49:04

tion that women would acquire in the public sphere were determined by the structural function of the virtues considered appropriate to their sex and to their assumed social milieu: the domestic setting.

\section{A RENOVATE VERSION OF FEMINIST ENLIGHTENMENT: EMILIA PARDO BAZÁN}

As Jovellanos' opinion concurred with the hegemonic and Enlightenment viewpoint, it is hardly surprising that in the following century - and in fact until the Spanish Civil War (1936-1939) - a series of feminist demands ensued. There were achievements like the foundation of important institutions such as the Escuela Normal de Maestras (Schoolteacher's Training College), the Escuela de Institutrices (School for Governesses) and the Association para la Enseñanza de la Mujer (Association for Women's Education) (1870), all under the auspices of Krausist thinkers like Fernando de Castro, Francisco Giner de los Ríos (creator and director the famous Institución Libre de Enseñanza or Free Educational Institution) and Adolfo Posada. But the outstanding figures of this historic period of Spanish feminism were the thinker and lawyer Concepción Arenal (1820-1893) and Emilia Pardo Bazán (1851-1921).

This latter was an exceptionally brilliant writer and one of the leading intellectual figures in Spain. Well versed in the thinking of the time, her feminist views evolved along the lines of the tradition we describe here, but now in a highly renovated version. Indeed, her own outlook comprised ideas from the landmark feminist thought of the day such as the British moral utilitarianism that she knew first hand. In 1890 she founded the editorial collection entitled "Biblioteca de la mujer" ("Women's Library"), which published the first translation into Spanish of The Subjection of Women by J.S. Mill, including a prologue written by her.

True to the moral principle of utility and utilitarian social liberalism, Bazán emphasised that the natural duty of women is the same as that of men: the autonomous (free) pursuit of happiness (in the sense of moral utilitarianism). To achieve this she believed women needed the same things as men: education to improve their rational capabilities, and access to all the public spheres of action. Only this way, claims Bazán, can human beings find happiness. However, they also need a social framework that permits the free competition between individuals, who will obtain their social position thanks to their own efforts and capabilities:

If we wish to have a sound basis for the criterion that should guide women's education, we must begin by promoting these rights. The purpose of education, according to James Mill, is to make the individual in question first and foremost an instrument of his own happiness, and secondly of that of his peers. In view of the relative and subordinate purpose of women's education to-

the formation of groups of women associates within the institution as he considered that this would involve them in the same type of disagreeable problems that beset men. 
day, Stendhal was utterly right when he said that women's education appears to have been designed deliberately and specifically to bring about their unhappiness ${ }^{18}$.

Bazán warned of the dangers of public language that extolled the excellence of women and their domestic role while it concealed their servitude. She also drew attention to the fact that education for men was inspired by the optimistic postulate (in the philosophical tradition of the Enlightenment) of faith in the perfectibility of rational human nature, and denounced the fact that women's education was derived from an unjustified and antinomic pessimistic postulate: the greater the intellectual perfection of women, the lower their moral perfection ${ }^{19}$. Pardo Bazán linked this pessimistic metaphysics with the reduction of feminine individuality to the reproductive functions of the species, and held Rousseau responsible for this atavistic belief ${ }^{20}$.

Elsewhere, Pardo Bazán's description of women's situation revealed a perceptive (and very contemporary) understanding of the means for making women consent to their own domination. She points out how women are educated to strive for an ideal model of womanhood that is constructed and sustained by an interweaving of philosophical, educational and political concepts.

In Bazán's view, the construction of women's submission was designed precisely to counteract or conceal the defects of deriving a right based on force. Force, she said, only achieves temporarily submission, whereas consent is accomplished by giving violence and servitude the appearance of duty and virtue.

She did not regard the submission of women as being different from any other process of domination, which - according to Pardo Bazán - rather than the result of an explicit design, is produced by an impulse guided by the collective interest of the dominant group. Another of Pardo Bazán's significant contributions - also very contemporary - is her denunciation of the tacit filters in place to exclude women, a phenomenon known today as the glass ceiling.

Bazán refers to this when she points out the incongruous political and cultural mechanism of what was then the new state system of higher education. This contradiction consisted in allowing women to have a university education and justifying it with a public rhetoric that paid lip service to equality, but which at the same time deployed tacit filters to prevent them from exercising $\mathrm{it}^{21}$.

In conclusion I would like to add that Pardo Bazán also declared herself in favour of suffrage for women. However, that struggle was taken up a few years

18 E. Pardo Bazán, La educación del hombre y de la mujer. Su relación y diferencias. Memoria leída en el Congreso Pedagógico Hispano-Luso-Americano, Madrid, Octubre, 1892, [in:] La mujer española, Madrid 1981, p. 77.

19 Ibidem, p. 74.

20 Ibidem, p. 75-76.

${ }^{21}$ Ibidem, p. 87. 
Pobrane z czasopisma Annales I - Philosophy and Sociology http://philosophia.annales.umcs.pl Data: 26/04/2023 14:49:04

later by Clara Campoamor (1888-1972) who - as a member of Parliament - in 1931 sponsored the passage of the right to vote for women during the second Republic in Spain.

This long feminist journey, in which we have here mentioned only a few figures, was brought to a sudden and dramatic halt with the Spanish Civil War and the throwback of the Franco era.

However feminist thought and movement resurfaced in Spain in clandestine anti-Franco groups, whose theoretical outlook revealed them to be very closely linked to the philosophy underlying the events of "May 1968" in France, and with the American feminist thinking associated with the sexual revolution.

With regard to contemporary feminist thought in Spain I will only say briefly - so as not to exceed the limits of this text - that in general there is a continuation of the classic idea that there is no justification for assigning social roles to women deriving from their reproductive functions. Apart from this, the Spanish philosophical feminist panorama is intellectually sophisticated, ample and diverse, in spite of the fact that we are currently in the grip of a strong neoconservative wave.

\section{BIBLIOGRAPHY}

Amar y Borbón J., Discurso en defensa del talento de las mujeres, y de su aptitud para el gobierno, $y$ otros cargos en que se emplean los hombres, www.ensayistas.org/antologia/XVIII/amarbor (access: 10.06.2015).

Amar y Borbón J., Discurso sobre la educación física y moral de las mujeres, Madrid 1790, http:// books.google.es/books/about/Discurso sobre_la_educacion_fisica_y_mor.html?id=LGXUxYlvoOIC (access: 10.06.2015).

Feijoo B.J., Discurso XVI. Defensa de las mujeres, [in:] Teatro crítico universal, Vol. 1, 1726, www.filosofia.org/bjf/bjft000.htm (access: 10.06.2015).

Jovellanos G.M., Dictamen... sobre renovar o revocar la prohibición de la introducción y uso de las muselinas (1784), [in:] V. Llombart, J. Ocampo (eds.), Obras completas, Vol. 10, Oviedo 2008.

Jovellanos G.M., Elogio de Carlos III, [in:] Poesía, Teatro, Prosa, Madrid 1980.

Pardo Bazán E., La educación del hombre y de la mujer. Su relación y diferencias. Memoria leída en el Congreso Pedagógico Hispano-Luso-Americano, Madrid, Octubre, 1892, [in:] La mujer española, Madrid 1981.

Perona A.J., Igualdad, [in:] C. Amorós (ed.), 10 palabras clave sobre mujer, Pamplona, Verbo Divino 1995.

Sarasua C., El siglo de la Ilustración, [in:] B.S. Anderson, J.P. Zinsser, Historia de las mujeres: una historia propia, Barcelona 1991.

\section{RESUMÉN}

En lo que sigue se bocetarán varios ejemplos del pensamiento crítico y feminista propio de la Ilustración española. Para perfilar mejor sus características, por un lado, se contrastará con el pensamiento feminista elaborado en el marco de la Ilustración francesa. Por otro lado, se contras- 
Pobrane z czasopisma Annales I - Philosophy and Sociology http://philosophia.annales.umcs.pl Data: 26/04/2023 14:49:04

116 Ángeles Jiménez Perona

tará con el pensamiento ilustrado español no feminista. Así mismo, con ayuda de esos ejemplos se mostrará cómo ese pensamiento feminista se centró muy especialmente en la noción de sujeto, la cual se iba forjando al tiempo que se pretendía instaurar un nuevo modelo de Estado y de sociedad.

Palabras clave: pensamiento crítico; teoría feminist; sujeto modern; Ilustración española 